\title{
Effect of Timing of Application of the Biological Control Agent Microsphaeropsis ochracea on the Production and Ejection Pattern of Ascospores by Venturia inaequalis
}

\author{
O. Carisse and D. Rolland
}

Agriculture and Agri-Food Canada, Horticultural Research Centre, 430 Gouin Blvd., Saint-Jean-sur-Richelieu, Québec, J3B 3E6, Canada. Accepted for publication 28 July 2004.

\begin{abstract}
Carisse, O., and Rolland, D. 2004. Effect of timing of application of the biological control agent Microsphaeropsis ochracea on the production and ejection pattern of ascospores by Venturia inaequalis. Phytopathology 94:1305-1314.

Field and in vitro trials were conducted to establish the influence of the biological control agent Microsphaeropsis ochracea on the ejection pattern of ascospores by Venturia inaequalis and on apple scab development, and to establish the best timing of application. The ejection pattern of ascospores was similar on leaves sprayed with $M$. ochracea and on untreated leaves. Fall application of $M$. ochracea combined with a delayedfungicide program was evaluated in orchards with intermediate and high scab risk. For both orchards, it was possible to delay the first three and two infection periods in 1998 and 1999, respectively, without causing significant increase or unacceptable leaf and fruit scab incidence. To evaluate the best timing of application, sterile leaf disks were inoculated with $V$. inaequalis and then with $M$. ochracea $0,2,4,6,8,10,12,14$, and 16 weeks later. After incubation under optimal conditions for pseudo-

M. ochracea was sprayed on scabbed leaves on seven occasions from August to November 1999 and 2000. Leaves were overwintered on the orchard floor and ascospore production was evaluated the following spring. Ascospore production was reduced by 97 to $100 \%$ on leaf disks inoculated with $M$. ochracea less than 6 weeks after inoculation with $V$. inaequalis, but ascospore production increased with increasing period of time when $M$. ochracea was applied 8 to 16 weeks after the inoculation with $V$. inaequalis. In the orchard, the greatest reduction in production of ascospores (94 to $96 \%$ in 2000 and $99 \%$ in 2001) occurred on leaves sprayed with $M$. ochracea in August. The production of ascospores was reduced by 61 to $84 \%$ in 2000 and $93 \%$ in 2001 on leaves sprayed with M. ochracea in September, reduced by 64 to $86 \%$ in 2000 and 74 to $89 \%$ in 2001 on leaves sprayed in October, and reduced by 54 and $67 \%$ in 2000 and 2001, respectively, on leaves sprayed in November. It was concluded that $M$. ochracea should be applied in August or September and that ascospore maturation models and delayed-fungicide program could be used in orchards treated with this biological control agent.
\end{abstract} thecia development, the number of ascospores was counted. Similarly,

Apple scab, caused by the fungal pathogen Venturia inaequalis (Cooke) G. Wint., is of major economic importance in the northeastern part of North America (38). If not managed, the disease can cause extensive losses following humid and cool weather conditions during the spring months. Direct losses result from fruit infections and indirect losses from defoliation, which can reduce tree vigor, winter hardiness, and subsequent yield (38).

The introduction of organic fungicides in the 1940s has had a major impact on the management of apple scab $(35,36)$; gradually, fungicides became the most important tool for the control of the disease. Fungicidal control generally is considered to be the sole economically feasible control measure against apple scab. However, this may change due to the high costs of new fungicides, increased fungicide resistance in populations of $V$. inaequalis, and increasing concerns of environmental costs and consumers' negative perceptions of fungicide use (3). Over the years, $V$. inaequalis has become less sensitive to fungicides such as dodine, benomyl, the DMI fungicides (sterol demethylation inhibitors), and the newly developed strobilurin-based fungicides $(9,16,32-34,44,51,52)$. Furthermore, cross resistance and partial cross resistance has been confirmed in populations of $V$. inaequalis from the United States (32). In addition, repeated use of

Corresponding author: O. Carisse; E-mail address: carisseo@agr.gc.ca

Publication no. P-2004-0924-01R

This article is in the public domain and not copyrightable. It may be freely reprinted with customary crediting of the source. The American Phytopathological Society, 2004
Additional keywords: pattern of ascospore ejection, sanitation.

fungicides can interfere with pest and predator balance and have adverse effect on predacious mites (6-8). There are also increasing health concerns for both farmers and consumers (49). For all of these reasons, interest in the development of alternative strategies to manage apple scab and to reduce reliance on fungicides is increasing $(14,54)$.

Although research in New York has shown that the fungus can overwinter as conidia on bud scales, $V$. inaequalis mostly overwinters in apple leaf litter (1). The main source of primary inoculum consists of ascospores that are produced within pseudothecia that develop in fallen leaves during the winter months. In the spring, at about the time of bud break, mature ascospores are forcibly ejected in response to rain (38). Ascospores continue to mature and are ejected over a period of 5 to 9 weeks, with a peak during the pink to petal fall apple phenological stages. Once ejected, ascospores are dispersed by wind. Few of the ascospores will reach the new growth of apple trees. The length of time required for infection depends on the number of hours of continuous wetness and the temperature during the wet period $(40,43)$.

In northeastern North America, most fungicide programs aim at controlling the primary infections caused by the ascospores, thus avoiding secondary cycles. Removal or destruction of the leaves on the orchard floor greatly reduces the amount of primary inoculum and, as a result, reduces the risk of infection. Apple leaf litter can be destroyed by shredding the leaves (54), application of urea or biological control agents, and by combining leaf shredding with treatments such as urea or fungal antagonists $(14,17,55)$.

Microsphaeropsis ochracea (Carisse \& Bernier), a coelomycete isolated from dead apple leaves, recently has been identified as a 
biological control agent of apple scab $(4,12,17,46)$. In in vitro studies, this antagonist inhibited 98.6 to $99.2 \%$ of the ascospores produced on leaf disks (46). In a similar study, application of M. ochracea on leaf disks incubated under controlled and orchard conditions resulted in 94 and $96 \%$ fewer ascospores (17). When M. ochracea was applied onto naturally infected leaves that were overwintered on the orchard floor, ascospore production the following spring was reduced by 76 to $84 \%$ (17). Fall applications of M. ochracea on the tree canopy (at $10 \%$ leaf fall) and on the ground (at 90\% leaf fall) were compared, resulting in 75.5 and $62 \%$ fewer ascospores, respectively (17). From this study, it was concluded that the biological control agent was slightly more effective when applied to the tree canopy, but the best timing of the application was unknown.

The objectives of this study were to (i) study the influence of fall application of $M$. ochracea on the ejection pattern of ascospores, (ii) evaluate the efficacy of $M$. ochracea under orchard conditions; and (iii) optimize the timing of application of $M$. ochracea. The information obtained was used to determine the best timing of application of $M$. ochracea and how fungicide spray programs should be adjusted in orchards treated with this biological control agent.

\section{MATERIALS AND METHODS}

Effect of $M$. ochracea on ejection pattern of ascospores by $\boldsymbol{V}$. inaequalis. A first set of experiments was conducted with detached apple leaves and repeated during four seasons (1995-96 to 1998-99). In early October 1994, 1995, 1996, and 1997, apple leaves (Malus pumila Mill. cv. McIntosh) that were naturally infected with $V$. inaequalis and showing typical scab lesions were collected at the Agriculture Canada Experimental Farm, in Frelighsburg, Québec, Canada. On 25 October 1995, 25 October 1996, 17 October 1997, and 8 October 1998, the scabbed leaves were inoculated with Microsphaeropsis ochracea, $1 \mathrm{ml}$ of mycelial slurry per leaf. The leaves then were overwintered in nylon mesh bags (50 leaves per bag) fixed to the orchard floor.

A second set of experiments (1996-97 and 1997-98) was conducted in a mature orchard of 0.41 ha planted with the cvs. McIntosh (58\%) and Lobo (42\%). The dwarf trees grafted on M26 rootstock were planted at a distance of 5 by $2.5 \mathrm{~m}$. M. ochracea was applied, either to the canopy of McIntosh trees at $10 \%$ leaf fall or as a ground application under McIntosh trees at $90 \%$ leaf fall, at a rate of 1,125 liters/ha of a spore suspension of $4.5 \times 10^{5}$ spores $/ \mathrm{ml}$. The tree canopy application was done on 11 October 1996 and 17 October 1997 and the ground application on 12 November 1996 and 26 November 1997. The spore suspension was applied using a gasoline-powered Solo backpack sprayer (model 422; Solo Sindelfingen, Germany) and a handheld gun. A single nozzle with a $80^{\circ}$ flat spray tip was operated at $620 \mathrm{kPa}$ with a flow rate of approximately 2.2 liters $/ \mathrm{min}$.

The effect of $M$. ochracea on the ejection of ascospores in the orchard was evaluated by measuring the airborne concentration of ascospores of $V$. inaequalis during each major rain event. Homemade impaction spore samplers (rotary impaction type) similar to the Rotorod device were used for this purpose $(17,18)$. The onset of rain or dew, which triggers ascospore liberation, was determined using electrical grid leaf wetness sensors installed at the ground level. The signal was transmitted to a datalogger (CR-10, Campbell Scientific, Edmonton, Canada), which in turn activated the spore samplers. Two spore samplers were installed in each of the three plots and ran consecutively for $4 \mathrm{~h}$ until the end of the rain or for a maximum of $8 \mathrm{~h}$. Ascospore infection is not possible once the leaves are dry; therefore, the end of the rain event was determined with the drying of the wetness sensors installed within the tree canopy. The sampling heads were set at $40 \mathrm{~cm}$ above the ground and shielded from the rain with a plastic cover $10 \mathrm{~cm}$ above the heads. The samplers were operated to spin at
2,400 rpm and to sample 19.99 liters of air per minute. For each rain conducive to ascospore ejection, the number of ascospores on the entire surface of the exposed area of the rods was counted under a microscope at $\times 250$, and the number of spores was transformed to ascospores per cubic meter as follows: (number of spores per $\operatorname{rod} \times 1,000$ liters $\left./ \mathrm{m}^{3}\right) /(19.99$ liters $/ \mathrm{min} \operatorname{rod} \times 60 \mathrm{~min} / \mathrm{h} \times$ running time in h). Airborne ascospore concentration was monitored from 1 May to 13 June 1997 and from 22 April to 11 June 1998, for a total of 11 and 10 rain events in 1997 and 1998, respectively.

Effect of fall treatment with $M$. ochracea on scab development the following spring. Experimental plots were established at the Agriculture Canada Experimental Farm, in Frelighsburg, Québec, Canada. The plots were established in two orchards selected based on their "scab risk" as determined by the method proposed by MacHardy (39). In the first orchard, the dwarf trees grafted on M26 rootstock were planted at a distance of 5 by $2.5 \mathrm{~m}$. Each row (except for border rows) was composed of a repeated motif of four trees of Summerland McIntosh separated by one or two trees of Lobo, and the border rows were planted with Lobo only. Both cultivars are considered susceptible to apple scab (14). This orchard was split into subplots of 0.14 ha. In the second orchard, the dwarf trees grafted on M26 rootstock were planted at a distance of 4.5 by $2.5 \mathrm{~m}$. This orchard, composed of McIntosh only, was split into subplots of 0.15 ha. Scab risk was estimated in each subplot on 28 September 1997 and 8 October 1998 using an adaptation of the method described by MacHardy (39) which is based on a late fall scab assessment. In each subplot, both surfaces of all leaves of 10 extension shoots from 10 trees selected at random were examined for the presence of scab lesions. When the number of scabbed leaves was $\leq 5$, between 5 and 25 , and $>25$, the subplot was considered to be at low, intermediate, and high risk, respectively. Because some treatments may influence the scab risk (i.e., cause an increase in the number of scab leaves present in the fall), each years the treatments were allocated randomly to the subplots within the two orchards.

M. ochracea was applied as described previously. To evaluate application efficacy, a sample of 15 to $25 \mathrm{ml}$ of the tank mix was collected during the application in the middle of each half-row application. The samples were kept on ice until the evaluation of spore concentration and spore germination. Within $24 \mathrm{~h}$, the spore concentration was estimated using a hemacytometer. Spore germination was evaluated by pouring $100 \mu \mathrm{l}$ of the solution onto water agar plates containing novobiocin $\left(100 \mu \mathrm{g} \mathrm{ml} \mathrm{m}^{-1}\right.$, Sigma-Aldrich, St. Louis), and observing the spores after $24 \mathrm{~h}$ of incubation at room temperature. Immediately after the application of the $M$. ochracea, five leaves per half row were collected and placed in plastic bags kept on ice. Within $24 \mathrm{~h}$, the leaves were blotted on a water agar plate amended with novobiocin $\left(100 \mu \mathrm{g} \mathrm{ml}^{-1}\right)$. The plates were kept at room temperature $\left(20\right.$ to $\left.25^{\circ} \mathrm{C}\right)$ with a $12-\mathrm{h}$ photoperiod and observed weekly for the presence of pycnidia during a period of up to 2 months. When pycnidia developed on the leaves, some of them were squashed and observed for the presence of spores typical of the M. ochracea (12).

To estimate the actual contribution of $M$. ochracea, the following four treatments were applied to four subplots within each orchard: no fall treatments and standard fungicide program; $M$. ochracea applied to the canopy at $10 \%$ leaf fall and delayedfungicide program; $M$. ochracea applied as a ground application under the trees at $90 \%$ leaf fall and delayed-fungicide program; and no fall treatment and delayed-fungicide program. For the $10 \%$ leaf fall application, M. ochracea was applied on 16 October 1997 and 17 October 1998. For the 90\% leaf fall application, M. ochracea was applied on 24 November 1997 and 13 November 1998. In the standard program, fungicides were applied to control all primary infection periods. In the delayed-fungicide program, fungicide application was delayed until after three infection periods or until the pink stage of bud development (which- 
ever came first), unless the spore samplers indicated that a large amount of ascospores were ejected during an infection period. The concentration of airborne ascospores of $V$. inaequalis was evaluated during each major rain event as described previously. Leaf scab incidence was evaluated three times during the growing season, on 24 June, 15 July, and 13 August 1998 and 30 June, 21 July, and 17 August 1999. Fruit scab incidence was evaluated at harvest. Leaf scab incidence was evaluated based on a sample of 10 trees, 10 shoots per tree, for a total of 200 shoots. Fruit scab incidence was evaluated based on a sample of 200 fruit per subplot.

Timing of application of $M$. ochracea: laboratory tests. In the fall of 1999 and 2000, disease-free apple leaves were collected from Malus domestica Borkh. 'McIntosh' trees at the Agriculture and AgriFood Canada research station in Frelighsburgh. Leaf disks, $2.7 \mathrm{~cm}$ in diameter, were cut and sterilized by irradiation (40 kGy [4 Mrad] of gamma radiation for $10 \mathrm{~h}$ ). Petri dishes, $9 \mathrm{~cm}$ in diameter, were filled with $20 \mathrm{ml}$ of autoclaved Perlite TM (Perlite Atlas Co. LTD., Beauport, Quebec, Canada) and $10 \mathrm{ml}$ of sterilized distilled water. The irradiated leaf disks were placed on top of the perlite (two disks per dish).

A mycelial suspension of $V$. inaequalis was made from equal parts of a mixture of five isolates collected in orchards in Quebec, Canada. A mixture of isolates was used to increase the number of pairs of compatible mating types and, consequently, ensure the production of pseudothecia. All isolates were previously grown separately on potato dextrose agar (PDA; Difco Laboratories, Detroit) at $18^{\circ} \mathrm{C}$. The growth rate of each isolate was different; therefore, when more than two-thirds of the surface of a $9-\mathrm{cm}$ petri dish was covered with growth, the dish was stored at $2^{\circ} \mathrm{C}$ until inoculation of the leaf disks. To prepare the mixture of $V$. inaequalis isolates, one petri dish of each isolate was placed in a sterile plastic bag (Steward Medical, London) along with $200 \mathrm{ml}$ of sterile water. The content of the bag was homogenized in a Stomacher laboratory blender (Seward Medical) for $1 \mathrm{~min}$ at normal speed. Sterile Eppendorf repeater-type Combitips TM syringes (Becton Dickinson, Canada Inc.) were used to draw the liquid directly from the bottom of the bag and to inoculate the disk surfaces. Each apple leaf disk was inoculated with $150 \mu \mathrm{l}$ of $V$. inaequalis suspension. In order to estimate the concentration of the inoculum (mycelial slurry), serial dilutions were made and $100 \mu \mathrm{l}$ of each dilution was spread onto petri dishes containing $10 \mathrm{ml}$ of PDA (three plates per dilution). The number of CFU was counted after 21 days of incubation at $18^{\circ} \mathrm{C}$.

Microsphaeropsis ochracea was stored in silicagel at $4^{\circ} \mathrm{C}$. and cultured at room temperature $\left(22\right.$ to $\left.25^{\circ} \mathrm{C}\right)$ on Difco PDA medium (Difco Laboratories) amended with novobiocin (100 $\mu \mathrm{g} \mathrm{ml} \mathrm{m}^{-1}$; Sigma-Aldrich). When mature pycnidia were present, mycelial slurries were prepared by homogenizing the cultures in $60 \mathrm{ml}$ of distilled sterile water with a Stomacher laboratory blender. For all inoculum preparations, the final concentration ranged from 1.21 to $3.04 \times 10^{2} \mathrm{CFU} / \mathrm{ml}$. Each leaf disk previously inoculated with $V$. inaequalis was inoculated with $150 \mu \mathrm{l}$ of this suspension. Sequential inoculation of the leaf disks with $M$. ochracea was done $0,2,4,6,8,10,12,14$, and 16 weeks after the inoculation of the leaf disks with $V$. inaequalis. For each inoculation, 10 dishes were inoculated along with a control consisting of 10 dishes inoculated only with $V$. inaequalis. The experiment was set up as a completely randomized design with 10 repetitions and the entire experiment was conducted twice. Several supplementary control dishes were prepared. These disks were used to follow the maturation of the pseudothecia and determine the developmental stage at the time of inoculation with M. ochracea (29) and to determine when the dishes should be placed under conditions that favor ascospore maturation and indicate when the ascospores were mature.

The incubation conditions were described previously by Philion et al. (46). This set of conditions was chosen to optimize the pro- duction and maturation of pseudothecia and ascospores. The leaf disks were maintained at room temperature for 3 weeks to allow $V$. inaequalis to colonize most of the disk surface. The dishes then were transferred to a cold room adjusted to $4{ }^{\circ} \mathrm{C}$ with $90 \%$ relative humidity (RH) in complete darkness for a period of 4 weeks; then transferred to another cold room adjusted to $10^{\circ} \mathrm{C}$ with $90 \% \mathrm{RH}$ and full darkness for an extra 10 to 12 weeks, depending on the degree of maturation of the pseudothecia in the controls. When most pseudothecia were mature, all the dishes were brought to the laboratory and kept at room temperature for another 2 to 3 weeks before ascospore extraction.

The production of ascospores on artificially inoculated leaf disks was evaluated at the end of the incubation period (19 to 21 weeks) determined by the presence of ascospores in pseudothecial squash mounts (23) prepared from control leaf disks inoculated only with $V$. inaequalis. To quantify ascospore production per leaf disk, two leaf disks were placed in a 50-ml Falcon test tube with $20 \mathrm{ml}$ of distilled water and exposed to air turbulence for $6 \mathrm{~h}$ (46). A few drops of Lugol's iodine solution were added to each tube to stop germination, and the tubes were then centrifuged at 3,800 rpm for $10 \mathrm{~min}$ (Accuspin FR, Beckman, CA). The liquid was carefully drawn out of each tube so that the pellet and surrounding liquid were not disturbed, to obtain $5 \mathrm{ml}$ of ascospore suspension. Ascospore concentration in each suspension was determined using a Fuchs Rosenthal R Haemocytometer (C.A. Hausser \& Son, Max Levy Inc.). Ascospore productivity was reported for each treatment as ascospores per square centimeter of leaf disk. The surface of two disks was $11.45 \mathrm{~cm}^{2}$ and the spore pellet was suspended in $5 \mathrm{ml}$, so the number of ascospores per square centimeter was calculated as (ascospore $/ \mathrm{ml} \times 5 \mathrm{ml}$ )/ $11.45 \mathrm{~cm}^{2}$.

Timing of application of $M$. ochracea: orchard trial with naturally infected leaves. The experiment was conducted during the 1999-2000 and 2000-01 seasons at the Agriculture and AgriFood Canada experimental farm in Frelighsburg, Québec, Canada. The experiment was conducted in a mature 0.41-ha orchard planted with cvs. McIntosh (58\%) and Lobo (42\%). The dwarf trees grafted on M26 rootstock were planted at a distance of 5 by $2.5 \mathrm{~m}$. On seven occasions, from mid-August to early November 1999 and 2000, scabbed McIntosh apple leaves of the cultivar were inoculated with a spore suspension of $M$. ochracea at a rate of $0.5 \mathrm{ml}$ per leaf of a suspension of $4.5 \times 10^{5}$ spores $/ \mathrm{ml}$. Inoculated leaves were enclosed in nylon mesh bags fixed to the branches. At the end of November, the bags were removed and fixed to the orchard ground for the overwintering period. In spring 2000 and 2001, the number of ascospores produced per leaf was quantified.

The production of ascospores on detached apple leaves was evaluated over the entire ascospore ejection period (i.e., from late April to the middle of June). One leaf was selected arbitrarily from each sampling unit (nylon bag) for a total of 10 leaves per treatment and placed on the wire bottom of a wooden spore trap (17) with the upper surface upward. Microscope slides, previously coated with petroleum jelly, were placed $0.5 \mathrm{~cm}$ above the leaves. After each major rain, all the slides were collected and replaced by new slides. Recovered slides were stored at $10^{\circ} \mathrm{C}$ until examination. The number of ascospores on $40 \%$ of the slide surface was counted under a microscope at a magnification of $\times 250$. Ascospore production then was expressed as the number of ascospores per centimeter of slide.

Statistical analysis. To test the effect of fall application of M. ochracea on the pattern of ascospores ejection, the number of ascospores trapped was transformed to seasonal proportion of ejected ascospores by dividing the number of ascospores trapped on a given date by the cumulative number of ascospores trapped for the entire season. Regression analysis was used to compare the seasonal proportion of ejected ascospores on leaves treated with $M$. ochracea in the fall and nontreated leaves. Analysis of 
variance was used to test the effect of fall treatment and delayedfungicide program the following spring on leaf and fruit scab and multiple comparison tests (least significant difference [LSD]) to detect significant differences among means. For the in vitro experiment, a test of homogeneity of variances ( $F$ test) was conducted to determine if data from the two experimental runs could be pooled and to ensure the underlying assumptions of the statistical models. Analysis of variance was used to test the effect of the length of the $V$. inaequalis incubation period before the application of $M$. ochracea (in weeks) on the total ascospore production. Multiple comparison tests (LSD) were performed to detect significant differences among means, and orthogonal comparison was performed to compare different incubation periods with the control ( $V$. inaequalis alone) at the 0.05 confidence level. Similarly, for the field trials, analysis of variance was used to test the effect of timing of application of $M$. ochracea on total production of ascospores and multiple comparison tests (LSD) to detect significant differences among means, and orthogonal comparison was performed to compare different timing of applications with the control ( $V$. inaequalis alone) at the 0.05 confidence level. Because the production of ascospores was measured over time and from the same leaves, the observations were not independent. Therefore, repeated measures analysis was used to test the effect of timing of application of $M$. ochracea on ascospore production for each sampling date (MANOVA procedure). All analyses were done using the Statistical Analysis System (SAS) program (version 8; SAS Institute, Cary, NC).

\section{RESULTS}

Effect of M. ochracea on ejection pattern of ascospores by $V$. inaequalis. When the number of ascospores of $V$. inaequalis trapped was transformed in proportion of ejected ascospores, the patterns of ascospore ejection over time for the leaves sprayed with $M$. ochracea was similar to that of untreated leaves (Fig. 1). For the 4 years of the experiment, 84, 76, 78, and 89\% less ascospores were collected from apple leaves sprayed in the fall with $M$. ochracea compared with the untreated leaves. When the experiment was conducted in orchard plots and $M$. ochracea applied onto the leaf canopy at $10 \%$ leaf fall and onto the ground at $90 \%$ leaf fall, a similar pattern of proportion of airborne ascospore concentration over time were observed in treated and nontreated plots (Fig. 2). However, in spring 1998, the number of ascospores trapped in plots where M. ochracea was applied the previous fall onto the tree canopy was lower than in nontreated plots or in plots treated the previous fall with $M$. ochracea applied to leaves on the ground. Regression analysis showed that there was a linear relationship between the proportion of season's ascospore matured and concentration of ascospore from leaves treated with $M$. ochracea and on nontreated leaves. The coefficient of determination $\left(R^{2}\right)$ was 0.91 and the intercept and rate parameters were not significantly different than 0 and 1, respectively (Fig. 3).

Effect of fall treatment with $M$. ochracea on scab development the following spring. The first orchard was considered at intermediate risk because the number of scabbed leaves varied from 15 to 21 and the second orchard was considered at high risk because the number of scabbed leaves varied from 107 to 135 (Table 1). When $M$. ochracea was applied, the final concentration and percent germination of the solutions applied in each subplot varied from $7.27 \times 10^{5}$ to $1.47 \times 10^{6}$ conidia/ml with 85 to $100 \%$ percent spore germination. M. ochracea was recovered from 83 to $100 \%$ of the leaves.

Fall treatment and fungicide program had a significant effect on both leaf scab $(P<0.0002$ and 0.0001 for 1998 and 1999, re-

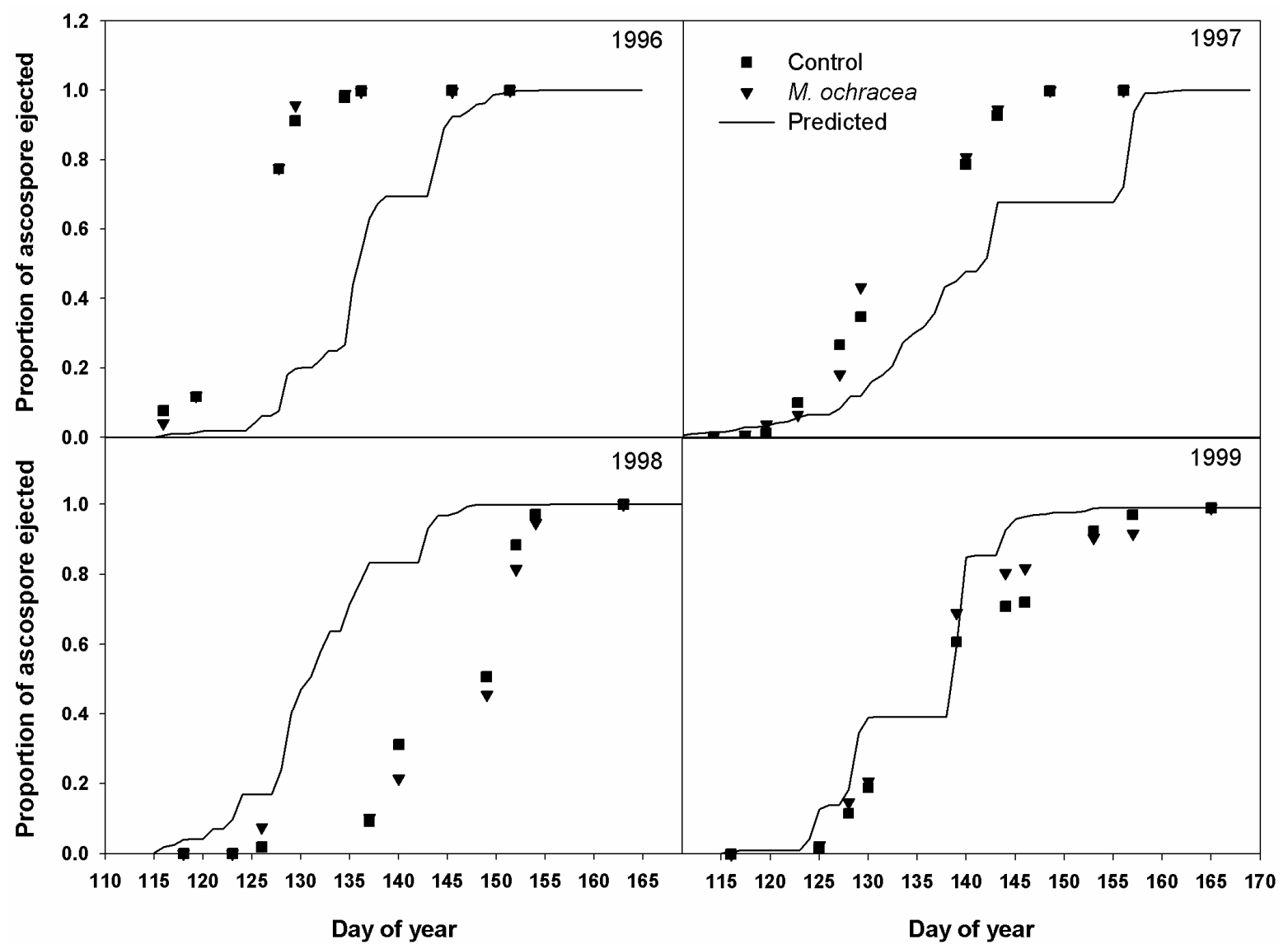

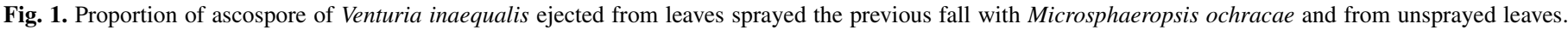

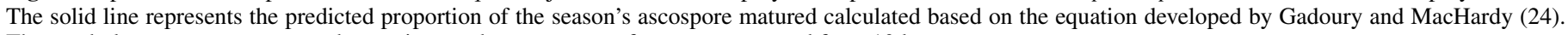
The symbols represent treatment observations and are averages of ascospore trapped from 10 leaves. 
spectively) and fruit scab $(P<0.0001)$. Apple scab was more severe in 1988 than in 1999 and, for both years, more scab developed in the high-risk orchard than in the intermediate-risk orchard (Fig. 4). For both years and both orchards, there was no significant difference between leaf scab incidence in the subplots sprayed the previous fall with $M$. ochracea either to the canopy at $10 \%$ leaf fall or as a ground application under trees at $90 \%$ leaf fall with delayed-fungicide program in the spring compared with the standard program without fall treatment and all infection periods controlled (Fig. 4). However, when no fall treatment was applied and the fungicide program delayed the following spring, leaf scab incidence was significantly higher than in the other subplots (Fig. 4). Fruit scab incidence was not significantly different in subplots sprayed in the fall with $M$. ochracea at $10 \%$ leaf fall with a delayed-fungicide program in the spring compared with the standard program without fall treatment and all infection periods controlled (Fig. 5). Fruit scab incidence was significantly higher in subplots sprayed in the fall with M. ochracea under trees at $90 \%$ leaf fall with a delayed-fungicide program in the spring and in subplots with a delayed-fungicide program in the spring compared with the standard program without fall treatment and all infection periods controlled (Fig. 5). The first three and two infection periods were not treated in the subplots sprayed according to the delayed-fungicide program in 1998 and 1999, respectively (Table 2). However, in the subplots where M. ochracea was applied the previous fall under trees at $90 \%$ leaf fall, the third and second infection periods in 1998 and 1999, respectively, were treated because a large amount of ascospores were trapped (Table 2).

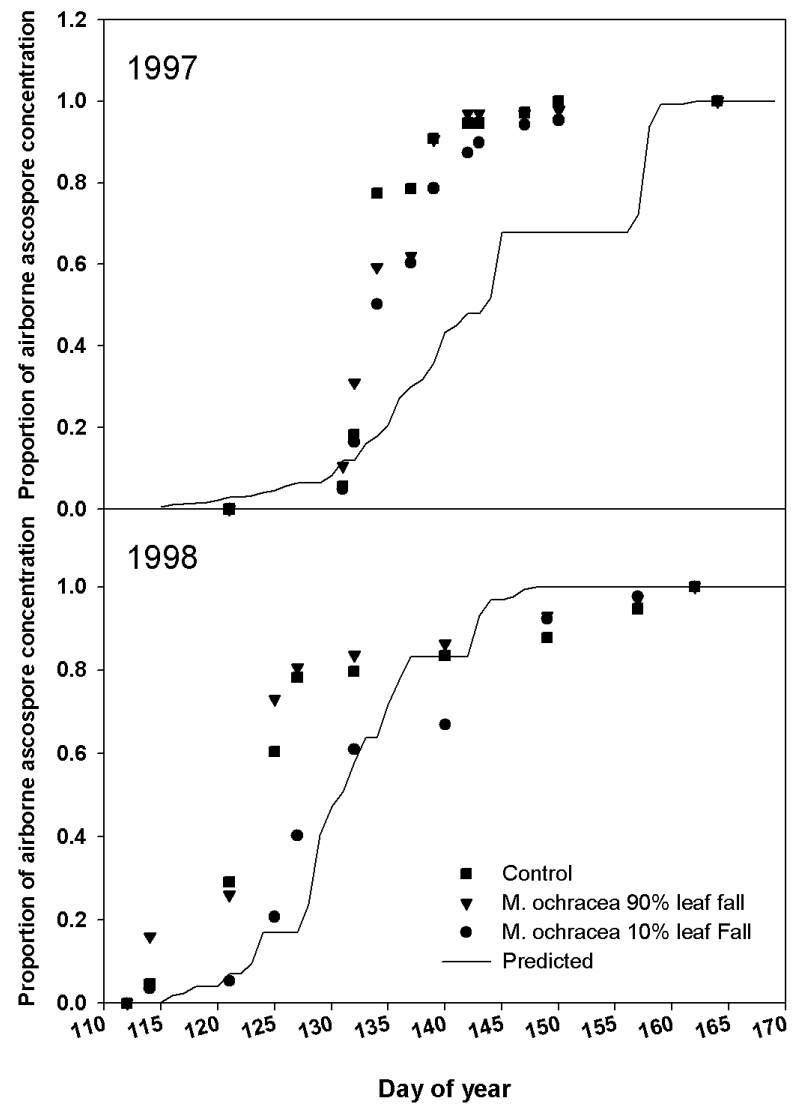

Fig. 2. Proportion of airborne ascospore concentration of Venturia inaequalis in orchard plots treated the previous fall with Microsphaeropsis ochracea applied as a foliar spray at $10 \%$ leaf fall or as a ground application at $90 \%$ leaf fall compared with a nontreated plot. Airborne ascospore concentrations were measured for each major rain event in spring 1997 and 1998. The solid line represents the predicted proportion season's ascospore matured calculated based on the equation developed by Gadoury and MacHardy (24).
Timing of application of $M$. ochracea: laboratory tests. The data from the two experimental runs were pooled based on homogeneity of variance $(P>0.05)$. Regardless of the time between the inoculations of the leaf disks with $V$. inaequalis and $M$. ochracea, significantly fewer ascospores $(P<0.0001)$ were produced on apple leaf disks treated with $M$. ochracea than on the disks inoculated with $V$. inaequalis only (Fig. 6.). Low numbers of ascospores were recorded for the leaf disks inoculated with $M$. ochracea 0,2 , 4 , and 6 weeks after inoculation with $V$. inaequalis, with 100, 99, 97, and $97 \%$ fewer ascospores, respectively. When $M$. ochracea was applied 8 to 16 weeks after the inoculation of the disks with $V$. inaequalis, the ascospores produced per square centimeter of apple leaf disk gradually increased with increasing period of time (Fig. 6). Based on phonological stages of development of the pseudothecia of $V$. inaequalis described by James and Sutton (32), the maximum stage observed (based on a sample of 20 observations) was noted on the day of inoculation of the leaf disks with M. ochracea. On leaf disks inoculated 2, 4, and 6 weeks after inoculation with $V$. inaequalis, the maximum stages observed were simple coiling (stage 2), formation of ascogonium from the initial (stage 3), and pseudoparaphyses beginning to appear as the ascogonium disappears (stage 5), respectively. On the leaf disks inoculated with $M$. ochracea, the pseudothecia matured from distinct pseudothecium (stage 6) 8 weeks after the inoculation with $V$. inaequalis to asci formed but contents not differentiated (stage 9) 16 weeks after the inoculation with $V$. inaequalis.

Timing of application of $M$. ochracea: orchard trial with naturally infected leaves. Overall, more ascospores were collected during spring 2000 than in 2001 (Fig. 7). Regardless of the timing of the fall applications, $M$. ochracea significantly $(P<$ 0.0001 and $P<0.0002$ for 2000 and 2001, respectively) reduced the production of ascospores compared with the untreated leaves (Fig. 7). The effect of timing of application of $M$. ochracea was similar for both seasons, with lowest production of ascospores when the scabbed apple leaves were sprayed with $M$. ochracea in August, followed by an increase in the production of ascospores when the leaves were treated in September and October (Fig. 7). When the apple leaves were sprayed in August, the production of ascospores the following spring was reduced by 94 to $96 \%$ in 2000 and $99 \%$ in 2001. When the leaves were sprayed in September, the production of ascospores was reduced by 61 to $84 \%$ in 2000 and $93 \%$ in 2001. When the apple leaves were sprayed in October, the production of ascospores was reduced by 64 to $86 \%$ in 2000 and 74 to $89 \%$ in 2001 . The early November application of $M$. ochracea resulted in 54 and $67 \%$ fewer ascospores the following spring in 2000 and 2001, respectively.

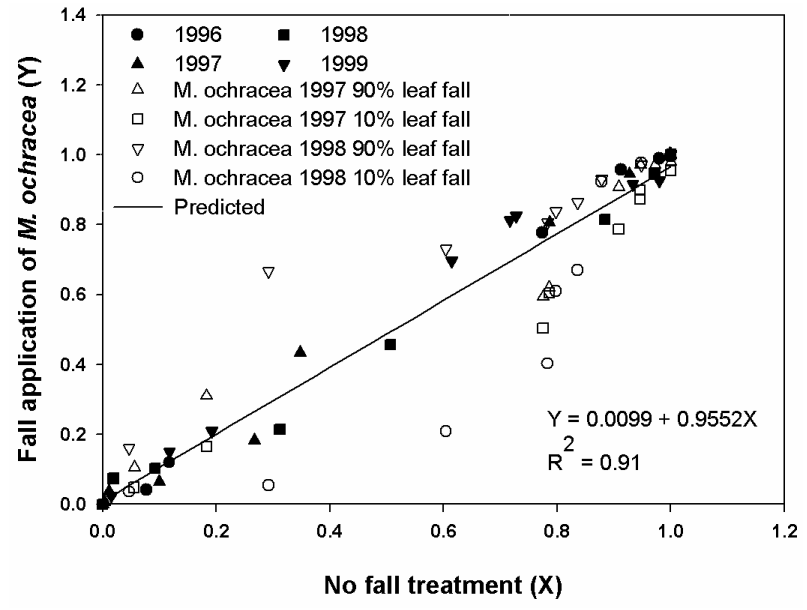

Fig. 3. Relationship between proportion of ascospores of Venturia inaequalis ejected on leaves treated the previous fall with Microsphaeropsis ochracea and with that of leaves that were not treated. 
For both years, the pattern of ascospore ejection over time was similar on treated and nontreated leaves (Fig. 8) regardless of when the scabbed leaves were sprayed with $M$. ochracea the previous fall. Repeated measures analysis revealed that there was a significant effect of timing of application $(P<0.0001)$ and time $(P<0.0001)$ and that the effect of timing of application on pro- duction of ascospores varied significantly over time $(P<0.05)$. The effect of timing of application on productions of ascospore was not significant when the amount of ascospores ejected was low. All applications of M. ochracea were done before leaf fall, which occurred around 8 November 1999 and 15 November 2000 .

TABLE 1. Assessment of apple scab made in late fall 1997, 1998, and 1999 in two different orchards and as affected by application of Microsphaeropsis ochracea and fungicide program ${ }^{\mathrm{a}}$

\begin{tabular}{|c|c|c|c|c|c|}
\hline \multirow[b]{2}{*}{ Orchard $^{\mathrm{b}}$} & \multirow[b]{2}{*}{ Treatment $^{c}$} & \multicolumn{4}{|c|}{ Scab leaves/100 shoots } \\
\hline & & 1997 & $1998^{\mathrm{d}}$ & $1998^{d}$ & 1999 \\
\hline Orchard I & $10 \%$ LF-delayed & 18 & 17 & 31 & 19 \\
\hline Orchard I & $90 \%$ LF-delayed & 15 & 24 & 23 & 58 \\
\hline Orchard I & Standard & 21 & 23 & 17 & 24 \\
\hline Orchard II & $10 \%$ LF-delayed & 135 & 102 & 149 & 114 \\
\hline Orchard II & 90\% LF-delayed & 127 & 152 & 152 & 167 \\
\hline
\end{tabular}

a Scab risk was estimated in each subplot on 28 September 1997, 8 October 1998, and 12 October 1999 using an adaptation of the method described by MacHardy (39) which is based on a late fall scab assessment. In each subplot, both surfaces of all leaves of 10 extension shoots from 10 trees selected at random were examined for the presence of scab lesions. When the number of scabbed leaves was $\leq 5$, between 5 and 25 , and $>25$, the subplot was considered at low, intermediate, and high risk, respectively.

${ }^{\mathrm{b}}$ In orchard I the dwarf trees grafted on M26 rootstock were planted at a distance of 5 by $2.5 \mathrm{~m}$. This orchard was composed of Summerland McIntosh Lobo. This orchard was split into subplots of 0.14 ha. In orchard II, the dwarf trees grafted on M26 rootstock were planted at a distance of 4.5 by $2.5 \mathrm{~m}$. This orchard composed of McIntosh only, was split into subplots of 0.15 ha.

${ }^{c}$ The treatments applied to four subplots within each orchard were no fall treatments and standard fungicide program (standard), M. ochracea applied to the canopy at 10\% leaf fall and delayed-fungicide program (10\% LF-delayed), M. ochracea applied as a ground application under the trees at $90 \%$ leaf fall and delayed-fungicide program (90\% LF-delayed), and no fall treatment and delayed-fungicide program (delayed).

${ }^{\mathrm{d}}$ In orchard I, the same subplots were used for the 2 years of the experiment and treatments were assigned randomly each year. In orchard II, different subplots were used each year.

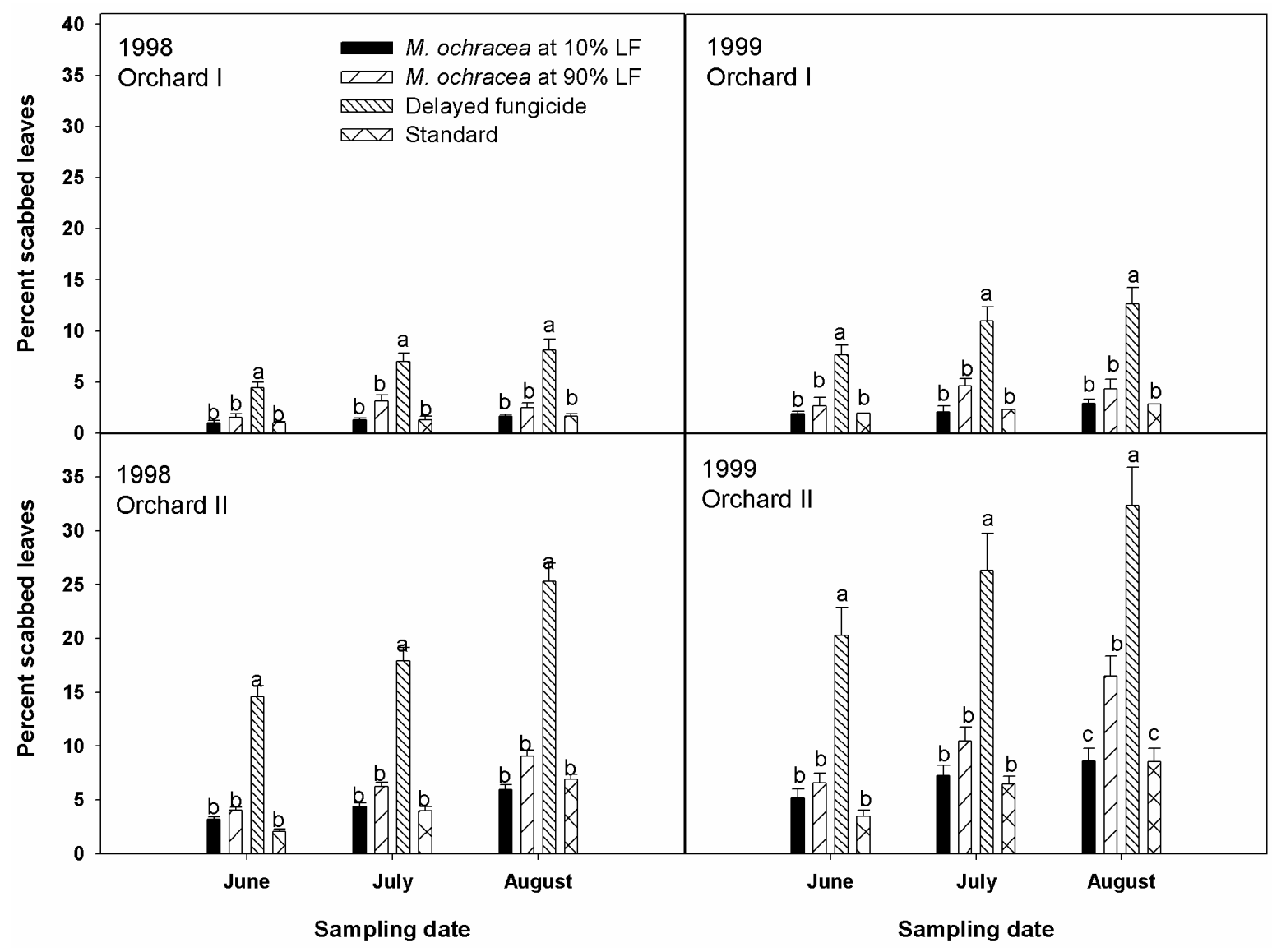

Fig. 4. Proportion of leaves with scab in subplots sprayed in the fall with Microsphaeropsis ochracea onto tree canopy at $10 \%$ leaf fall (10\% LF-delayed) and onto the ground at $90 \%$ leaf fall (90\% LF-delayed) with delayed fungicide program in the spring, not sprayed in the fall with delayed fungicide program in the spring (Delayed), and not sprayed in the fall with all infection periods controlled next spring (Standard). Bars with the same letters are not significantly different according to the least significant difference test at the 0.05 level of confidence. Orchard I was considered at intermediate scab risk and orchard II at high scab risk (39). 


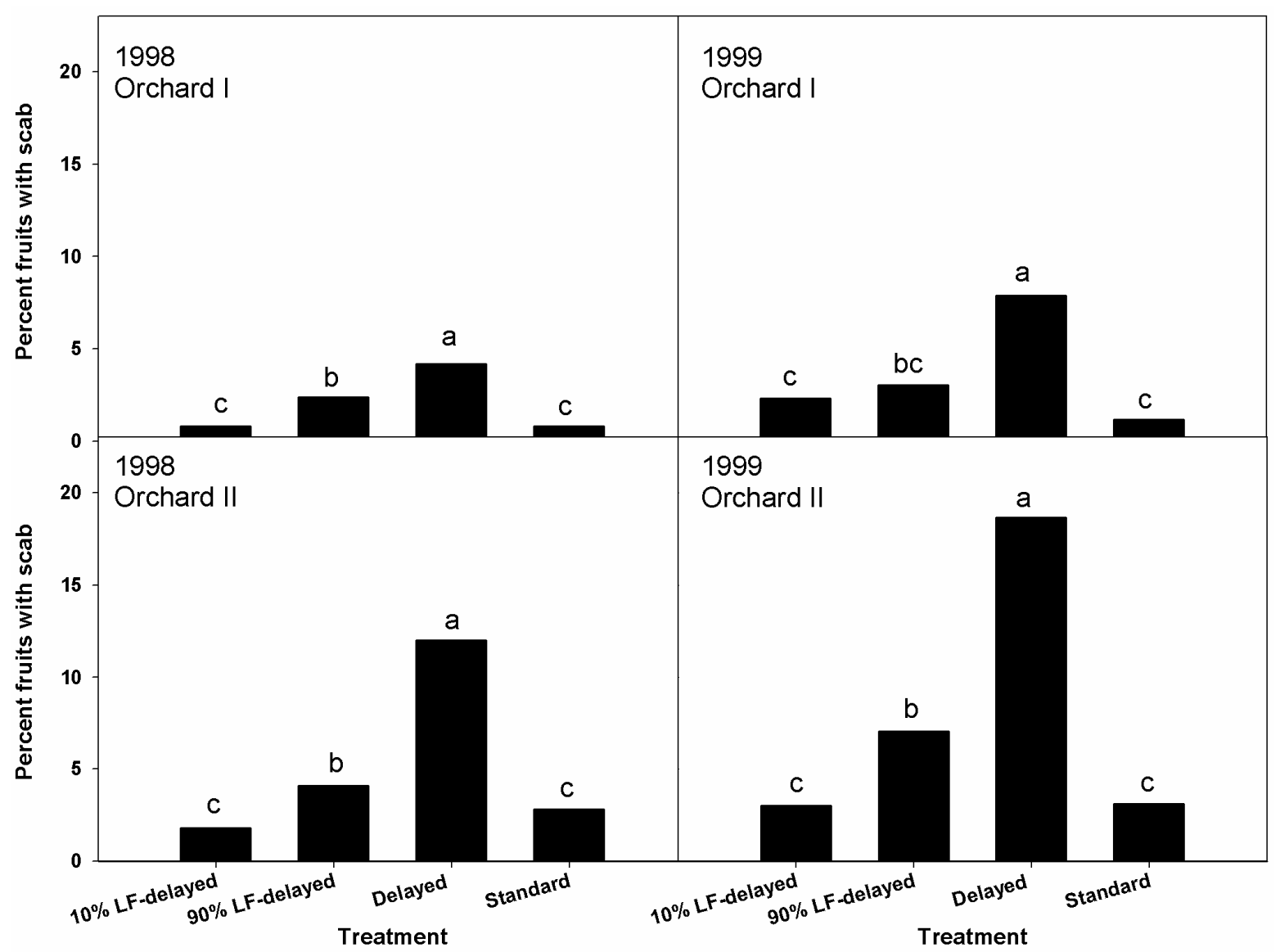

Fig. 5. Proportion of fruit with apple scab in subplots sprayed in the fall with Microsphaeropsis ochracea onto the canopy at 10\% leaf fall (10\% LF-delayed) and onto the ground at $90 \%$ leaf fall (90\% LF-delayed) with delayed fungicide program in the spring, not sprayed in the fall with delayed fungicide program in the spring (Delayed), and not sprayed in the fall with all infection periods controlled next spring (Standard). Bars with the same letters are not significantly different according to the least significant difference test at the 0.05 level of confidence. Orchard I was considered at intermediate scab risk and orchard II at high scab risk (39).

TABLE 2. Description of the fungicide programs used during spring 1998 and $1999^{\mathrm{a}}$

\begin{tabular}{|c|c|c|c|c|c|c|}
\hline Year, fungicide & Rate $(\mathrm{kg} / \mathrm{ha})$ & Date applied & Standard & Delayed & $10 \%$ LF-delayed & 90\% LF-delayed \\
\hline \multicolumn{7}{|l|}{1998} \\
\hline Polyram 80DF & 3.60 & 24 April & $\mathrm{X}$ & - & - & - \\
\hline Dithane GD & 4.80 & 1 May & $\mathrm{X}$ & - & - & - \\
\hline Nova 40WP & 0.153 & 7 May & $X$ & $\mathrm{X}$ & $X$ & $\mathrm{X}$ \\
\hline Captan 80WP & 1.69 & 13 May & $\mathrm{X}$ & $X$ & $\mathrm{X}$ & $X$ \\
\hline Captan 80WP & 1.69 & 20 May & $\mathrm{X}$ & $\mathrm{X}$ & $\mathrm{X}$ & $X$ \\
\hline Maestro 75DF & 4.00 & 28 May & $\mathrm{X}$ & $\mathrm{X}$ & $\mathrm{X}$ & $\mathrm{X}$ \\
\hline \multicolumn{7}{|l|}{1999} \\
\hline Polyram 80DF & 6.00 & 5 May & $X$ & - & - & - \\
\hline Captan 80WP & 1.69 & 7 May & $\mathrm{X}$ & - & - & $\mathrm{X}$ \\
\hline Nova 40WP & 0.153 & 11 May & $\mathrm{X}$ & $\mathrm{X}$ & $\mathrm{X}$ & $\mathrm{X}$ \\
\hline Polyram 80DF & 3.00 & 11 May & $X$ & $\mathrm{X}$ & $\mathrm{X}$ & $X$ \\
\hline Nova 40WP & 0.340 & 21 May & $X$ & $\mathrm{X}$ & $\mathrm{X}$ & $X$ \\
\hline Captan 80WP & 1.80 & 11 June & $\mathrm{X}$ & $\mathrm{X}$ & $\mathrm{X}$ & $\mathrm{X}$ \\
\hline Nova 40WP & 0.340 & 11 June & $\mathrm{X}$ & $\mathrm{X}$ & $\mathrm{X}$ & $\mathrm{X}$ \\
\hline
\end{tabular}

${ }^{a} \mathrm{X}$ indicates that fungicide was applied and - indicates that fungicide was not applied. The treatments applied were no fall treatments and standard fungicide program (standard), no fall treatment and delayed-fungicide program (delayed), Microsphaeropsis ochracea applied to the canopy at 10\% leaf fall and delayedfungicide program (10\% LF-delayed), and M. ochracea applied as a ground application under the trees at $90 \%$ leaf fall and delayed-fungicide program ( $90 \%$ LF-delayed). 


\section{DISCUSSION}

In most apple-production areas, frequent applications of fungicide have been and are still the main approach to manage apple scab (38). Over the years, researchers have developed several tools to effectively target the applications of fungicide during the primary stage of apple scab development by integrating models or techniques to estimate the potential ascospore dose or scab risk

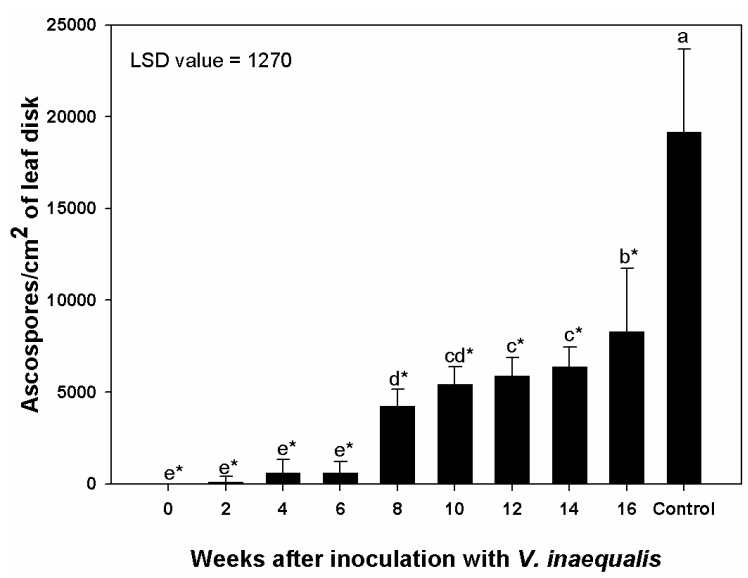

Fig. 6. Production of ascospores of Venturia inaequalis on leaf disks inoculated with Microsphaeropsis ochracea 0, 2, 4, 6, 8, 10, 12, 14, and 16 weeks after inoculation with $V$. inaequalis. Bars with the same letters are not significantly different according to the least significant difference test (LSD at the 0.05 level of confidence). Bars with * are significantly different from the control (not inoculated with $M$. ochracea) based on orthogonal comparisons $(P=0.05)$. Data from the two experimental runs were pooled.
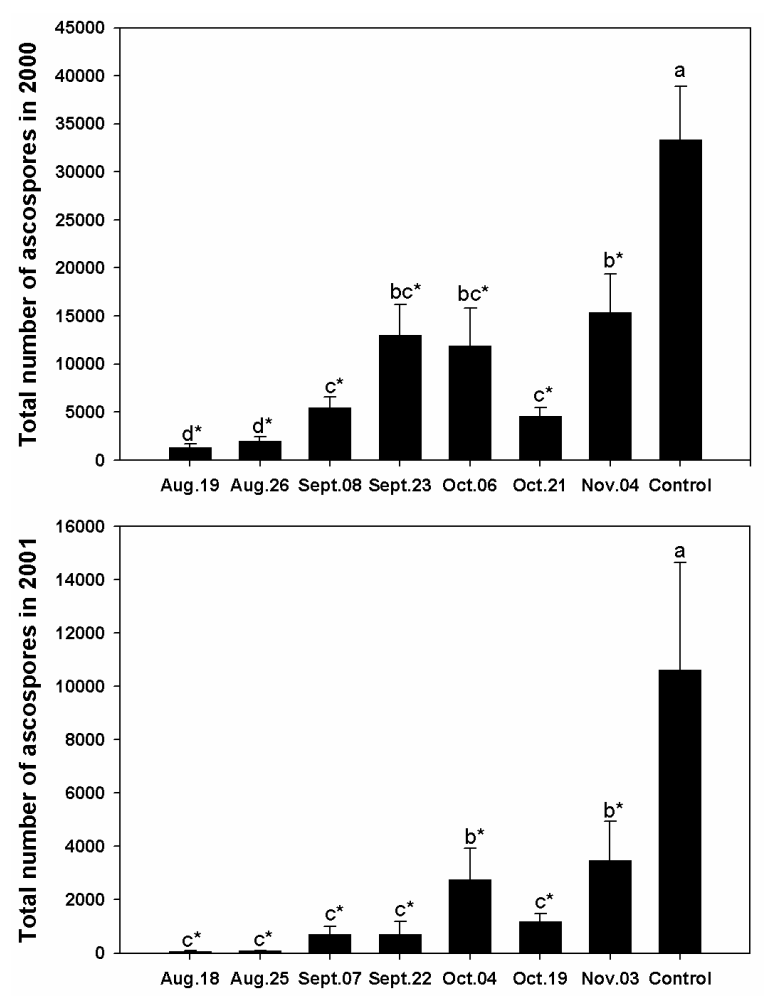

Date of application $M$. ochracea in the orchard

Fig. 7. Total production of ascospores by Venturia inaequalis from detached scabbed leaves sprayed with Microsphaeropsis ochracea on different dates in the fall. The production of ascospores was measured for eight major rain events in 2000 and 2001. Bars with the same letters are not significantly different according to the least significant difference test (LSD at the 0.05 level of confidence). Bars with * are significantly different from the control (nontreated leaves) based on orthogonal comparisons $(P=0.05)$.
$(25,37,39,41)$, ascospore maturity in the spring $(24,30,53)$, and risk of infection period (40,43). MacHardy et al. (41) showed that delaying the first sprays in orchards with a low potential ascospore dose does not result in significantly or unacceptable fruit scab at harvest. Furthermore, to aid in decision making on whether early spring fungicide application could be eliminated without significant increase in the incidence of fruit scab at harvest, action thresholds based on fall scab assessments have been developed (39). Thus, the reduction of primary inoculum is crucial for optimal management of apple scab.

Conidia and mycelium of $V$. inaequalis do not survive the low temperature and freezing of colder climates (1). Consequently, ascospores are the main source of primary inoculum. It has been known for more than a century that $V$. inaequalis overwinters in scabbed leaves (50), but the relationship between the amount of scab lesions on leaves present in the leaf litter and the amount of inoculum was only established by Curtis in 1924 (20). Methods for destroying $V$. inaequalis in leaves have been studied for more than 70 years (14). Early studies used materials such as lime sulfur or Bordeaux mixtures applied to the leaves either on the tree just prior to leaf fall or to leaves on the ground. More recent studies have examined the effects of applications of benzimidazole and sterol inhibiting fungicides just prior to leaf fall (21). These fungicides were very effective at reducing the primary inoculum; however their use has been discouraged because of the possibility of developing resistance $(5,31,45)$.

Sanitation measures disappeared from the recommendations until 1990, when similar effects of leaf removal on reduction of initial inoculum were reported by Rosenberger in 1990 (47) and subsequently by Sutton et al. in 2000 (54). Sutton et al. (54) reported that, if all apple leaves were shredded in the fall or in the early spring, the primary inoculum was reduced by 80 to $90 \%$. However, the authors also reported that, when incomplete shred-
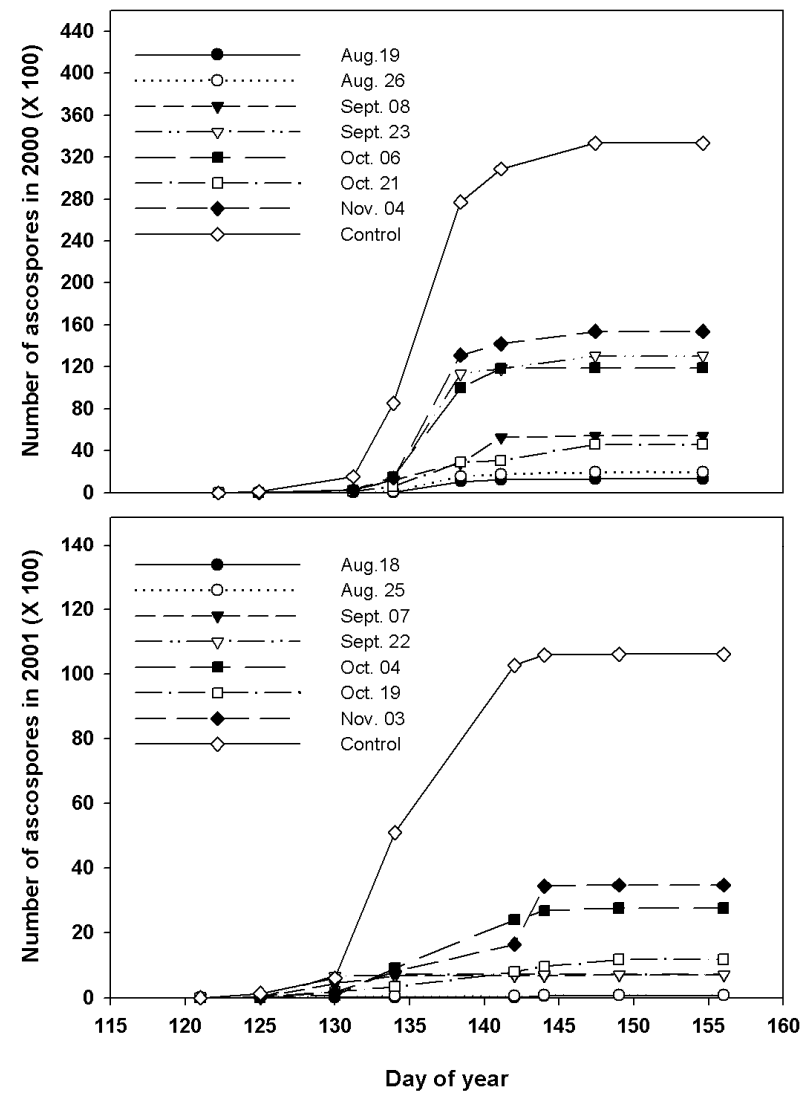

Fig. 8. Production of ascospores by Venturia inaequalis over time from detached scabbed leaves sprayed with Microsphaeropsis ochracea on different dates in the fall. Each value is an average of ascospore production from 10 leaves. 
ding of leaves was done, primary inoculum was reduced by only 50 to $65 \%$. Leaf shredding or removal is weather dependant because it can be done only when most leaves are on the ground and depends on the region, because this may be at the time of first snowfall.

Several researchers $(10,11,19,26,48,54)$ studied the role of urea in the inhibition of $V$. inaequalis pseudothecia development. Fall application of urea induces modifications in chemical and microbial components of apple leaf surfaces and causes deterioration of the physical structure of the leaves, which contributes to the suppression of the production of ascospores (19). Despite the apparent effect of urea application on ascospore production, very few large-scale experiments have been conducted. In such an experiment, Sutton et al. (54) reported a decrease in relative ascospore dose of $74 \%$ following a spring application of urea on leaf litter. In the same study, the fall application of $5 \%$ urea failed to significantly reduce ascospore production. Biosanitation (i.e., the use of a biological control agent to prevent disease by the reduction of primary inoculum) is one avenue for management of primary inoculum.

Researchers have investigated the possibility of using fungal antagonists to interfere with pseudothecial development of $V$. inaequalis $(14,27,28)$. Athelia bombacina was selected based on its ability to inhibit pseudothecial development. In a field trial, Young and Andrews (56) showed that A. bombacina inhibits hyphal growth and initiation of pseudothecia by $V$. inaequalis. However, complete pseudothecial inhibition was obtained in field trials only when very high doses of the antagonist inoculum were used $(27,28)$. When a lower rate was used, pseudothecial inhibition was reduced to only 60 to $70 \%$ (42). Up to now, A. bombacina has not been developed as a commercial biological control agent.

In previous studies, $M$. ochracea was identified as a good antagonist of $V$. inaequalis $(17,46)$; however, its effect on ejection pattern of ascospores and scab development has not been established. The results of the present study showed that, although a late-summer application of $M$. ochracea reduced the production of ascospores of $V$. inaequalis the following spring by $\approx 90 \%$, the ejection pattern of ascospores over time was not modified. This is important because it means that maturation models developed for different apple-growing areas $(24,30,53)$ could be used in orchards treated with $M$. ochracea. In this study, M. ochracea was evaluated as a sanitation practice in orchards with moderate and high scab risk. The first three and two infection periods, in 1998 and 1999, respectively, were not treated with fungicide in the plots sprayed the previous fall with $M$. ochracea at $10 \%$ leaf fall without causing significant increase in fruit scab incidence. When the same infection periods were not treated with fungicides in plots not sprayed the previous fall with $M$. ochracea, the fruit scab incidence was significantly higher and at a level unacceptable for growers. Furthermore, for both years and both orchards, the delayed-fungicide program in plots sprayed the previous fall with $M$. ochracea did not result in an increase in scab risk. Delaying fungicide program would reduce the total amount of fungicide applied per orchard and, consequently, reduce costs of labor, equipment, and material, as well as early season passes through the orchard under wet conditions. Reduction in amount of fungicide applied also may reduce pressure for the development of fungicide resistance in $V$. inaequalis population.

Previous studies showed that $M$. ochracea has the potential to reduce the production of ascospore by 81 to $96 \%(17,46)$. However, in large field trials, the reduction in ascospore production was only $75.27 \%$, indicating the need for optimization, including timing of application. Because $M$. ochracea was isolated on leaf litter (4) and accelerated leaf decomposition (46), and because wetness of leaf litter usually is not a limiting factor in the fall, it was hypothesized that this antagonist should be applied on leaf litter at $\approx 90 \%$ leaf fall. However, there are limitations to this approach. In a previous study, greater reduction in the production of ascospores was observed when $M$. ochracea was applied onto the apple tree canopy at the time of $10 \%$ leaf fall (17). M. ochracea germinates and grows best at temperatures from 20 to $25^{\circ} \mathrm{C}$ (13), which is more likely to occur at $10 \%$ leaf fall stage than at the $90 \%$ leaf fall stage when the average daily temperature is low (below $20^{\circ} \mathrm{C}$ ); and, if snow cover is present, ground applications will not be feasible.

Timing of application is critical for chemical as well as for biological fungicides. M. ochracea, for example, is capable of reducing initial inoculum of $V$. inaqualis by $\approx 80 \%$ (17), but the best timing of application was unknown. In the present study, the in vitro and orchard experiments showed that $M$. ochracea was most effective when applied during late summer or early fall rather than during late fall. Under laboratory conditions, $M$. ochracea was more efficient at reducing the production of ascospores by $V$. inaequalis when it was applied before the formation of distinct pseudothecium. The exact mode of action of $M$. ochracea is not understood, but the higher efficiency of late-summer applications may be explained by the parasitic activity and the attraction of $M$. ochracea to melanized fungal structures, including mycelium of $V$. inaequalis $(2,15,22)$. It could be that $M$. ochracea, when applied on apple leaves, is attracted by apple scab lesions (presence of tissues with necrosis and of fungal melanin) (22). Another possibility is that $M$. ochracea colonizes the lesion and parasitizes $V$. inaequalis mycelium, preventing mating and, later, the formation of pseudothecia.

The use of M. ochracea should be considered as a sanitation or orchard hygiene practice and not as a replacement for fungicides during the primary scab season. It probably could be best used in conjunction with a fall assessment of potential ascospore dose (PAD) $(25,37,39,41)$. Knowing ahead of time how much primary inoculum is expected in the orchard can assist growers in developing control strategies the following spring. For example, in orchards with high inoculum (high PAD), M. ochracea could be used to reduce the inoculum potential and, consequently, bring the scab risk down to a manageable level. In orchards with low inoculum potential, $M$. ochracea could be used to secure delayedfungicide spray strategies $(39,41)$.

\section{ACKNOWLEDGMENTS}

This work was financially supported by a Matching Investment Initiative between Agriculture and Agri-Food Canada and PhilomBios.

\section{LITERATURE CITED}

1. Becker, C. M., Burr, T. J., and Smith, C. A. 1992. Overwintering of conidia of Venturia inaequalis in apple buds in New York. Plant Dis. 76:121-126.

2. Benyagoub, M., Benhamou, N., and Carisse, O. 1997. Cytochemical investigation of the antagonistic interaction between Microsphaeropsis sp. (isolate P130A) and Venturia inaequalis. Phytopathology 88:605-613.

3. Beresford, R. M., and Manktelow, D. W. L. 1994. Economics of reducing fungicide use by weather-based disease forecasts for control of Venturia inaequalis in apples. N. Z. J. Crop Hortic. Sci. 22:113-120.

4. Bernier J., Carisse O., and Paulitz, T. C. 1996. Fungal communities isolated from dead apple leaves from orchards in Quebec. Phytoprotection 77:129-134.

5. Biggs, A. R., and Warner, J. 1990. Full-season and post-harvest application of sterol-inhibiting fungicides to reduce ascospore formation in Venturia inaequalis. Phytoprotection 71:9-15.

6. Bostanian, N. J., and Laroque, N. 2001. Laboratory tests to determine the intrinsic toxicity of four fungicides and two insecticides to the predacious mites Agistemus fleschneri. Phytoparasitica 29:215-222.

7. Bostanian, N. J., Thistlewood, H., and Racette, G. 1998. Effects of five fungicides used in Quebec apple orchards on Amblyseius fallacies (Garman) (Phytoseiidae: Acari). J. Hortic. Sci. Biotechnol. 73:427-450.

8. Bower, K. N., Berkett, L. P. and Costante, J. F. 1995. Nontarget effect of a fungicide spray program on phytophagous and predacious mite populations in a scab resistant apple orchard. Environ. Entomol. 24:423-430.

9. Braun, P. G., and McRae, K. B. 1992. Composition of a population of Venturia inaequalis resistant to myclobutalanil. Can. J. Plant Pathol. 14:215-220. 
10. Burchill, R. T., and Cook, R. T. A. 1970. The interaction of urea and micro-organism in suppressing the development of perithecia of Venturia inaequalis (Cke) Wint. Pages 471-483 in: Ecology of Leaf Surface MicroOrganisms. T. F. Preece and C. H. Dickinson, eds. Academic Press, New York.

11. Burchill, R. T., and Hutton, K. E. 1965. The suppression of ascospore production to facilitate the control of apple scab (Venturia inaequalis (Cke) Wint.). Ann. Appl. Biol. 56:285-292.

12. Carisse, O., and Bernier, J. 2001. Microsphaeropsis ochracea sp. nov. associated with dead apple leaves. Mycologia 94:297-301.

13. Carisse, O., and Bernier, J. 2002. Comparison of four Microsphaeropsis isolates: Biological control potential and effect of environmental factors on growth, pycnidial production and spore germination. Mycol. Res. 106:1-8.

14. Carisse, O., and Dewdney, M., 2002. A review of non-fungicidal approaches for the control of apple scab. Phytoprotection 83:1-29.

15. Carisse, O., El Bassam, S., and Benhamou, N. 2001. Effect of Microsphaeropsis sp. (strain P130A) on germination and production of sclerotia of Rhizoctonia solani and interaction between the antagonist and the pathogen. Phytopathology 91:782-791.

16. Carisse, O., and Pelletier, J. R. 1994. Sensitivity distribution of Venturia inaequalis to fenarimol in Québec apple orchards. Phytoprotection 75:35-43.

17. Carisse, O., Philion, V. Rolland, D., and Bernier, J. 2000. Effect of fall application of fungal antagonists on spring ascospore production of apple scab pathogen, Venturia inaequalis. Phytopathology 90:31-37.

18. Charest, J, Debwney, M., Paulitz, T., Philion, V., and Carisse, O. 2002. Spatial distribution of Venturia inaequalis airborne ascospores under commercial orchard conditions. Phytopathology 92:769-779.

19. Cross, J. E., Garrett, C. M. E., and Brichill, R. T. 1968. Changes in the microbial population of apple leaves associated with the inhibition of the perfect stage of Venturia inaequalis after urea treatment. Ann. Appl. Biol. 61:203-216.

20. Curtis, K. M. 1924. Black spot of apple and pear. N. Z. J. Dep. Agric. 28:21-28.

21. Darpoux, H., Lebrun, A., and Tullaye, B. 1975. Action de traitement sur la formation des périthèces et la production de l'inoculum primaire de Venturia inaequalis (Cooke) Wint. et de Venturia pirina Adher. Phytiatr. Phytopharm. Rev. Fr. Med. Pharm. Veg. 24:3-14.

22. El Bassam, S., Benhamou, N., and Carisse, O. 2002. The role of melanin in the antagonistic interaction between the apple scab pathogen Venturia inaequalis and Microsphaeropsis ochracea. Can. J. Microbiol. 48:349358.

23. Gadoury, D. M., and MacHardy, W. E. 1982. Preparation and interpretation of squash mounts of pseudothecia Venturia inaequalis Phytopathology 72:92-95.

24. Gadoury, D. M., and MacHardy, W. E. 1982. A model to estimate the maturity of ascospores of Venturia inaequalis. Phytopathology 72:901904.

25. Gadoury, D. M., and MacHardy, W. E. 1986. Forecasting ascospore dose of Venturia inaequalis in commercial apple orchards. Phytopathology 76:112-118.

26. Gupta, G. K., and Lele, V. C. 1980. Role of urea in suppression of ascigerous stage, and comparative in-vitro efficacy of fungicides against apple scab. Indian J. Agric. Sci. 50:167-173.

27. Heye, C. C. 1982. Biological control of the perfect stage of the apple scab pathogen, Venturia inaequalis (Cke) Wint. Ph.D. thesis. University of Wisconsin, Madison.

28. Heye, C. C., and Andrews, J. H. 1983. Antagonism of Athelia bombacina and Chaetomium globosum to the apple scab pathogen Venturia inaequalis. Phytopathology 73:650-654.

29. James, J. R., and Sutton, T. B. 1982. Environmental factors influencing pseudothecial development and ascospore maturation of Venturia inaequalis. Phytopathology 72:1073-1080.

30. James, J. R., and Sutton, T. B. 1982. A model for predicting ascospore maturation of Venturia inaequalis. Phytopathology 72:1081-1085.

31. Keitt, G. W., Clayton, C. N., and Langford, M. H. 1941. Experiments with eradicant fungicides for combating apple scab. Phytopathology 31:296-322.
32. Köller, W., and Wilcox, W. F. 2001. Evidence for the predisposition of fungicide-resistant isolates of Venturia inaequalis to a preferential selection for resistance to other fungicides. Phytopathology 91:776-781.

33. Köller, W., Parker, D. M., and Reynolds, K. L. 1991. Baseline sensitivities of Venturia inaequalis to sterol demethylation inhibitors. Plant Dis. 75:726-728.

34. Kunz, S., Deising, H., and Mendgen, K. 1997. Acquisition of resistance to sterol demethylation inhibitors by populations of Venturia inaequalis. Phytopathology 87:1272-1278.

35. Lewis, F. H. 1980. Control of deciduous tree fruit diseases: A success story. Plant Dis. 64:258-263.

36. Lewis, F. H., and Hickey, K. D. 1972. Fungicides usage on deciduous fruit tree. Annu. Rev. Phytopathol. 10:399-428.

37. MacHardy, W. E. 1994. A 'PAD' action threshold: The key to integrating practices for managing apple scab. Pages 75-82 in: Integrated Control of Pome Fruit Diseases. D. J. Butt, ed. Noew. J. Agric. Sci. Suppl. No 17.

38. MacHardy, W. E. 1996. Apple Scab: Biology, Epidemiology, and Management. The American Phytopathological Society, St. Paul, MN.

39. MacHardy, W. E. 1998. Action thresholds for managing apple scab with fungicides and sanitation. Acta 525:123-131.

40. MacHardy, W. E., and Gadoury, D. M. 1989. A revision of Mill's criteria for predicting apple scab infection periods. Phytopathology 79:304-310.

41. MacHardy, W. E., Gadoury, D. M., and Rosenberger, D. A. 1993. Delaying the onset of fungicide programs for the control of apple scab in orchards with low potential ascospores dose of Venturia inaequalis. Plant Dis. 77:372-375.

42. Miedtke, U., and Kennel, W. 1990. Athelia bombacina and Chaetomium globosum as antagonists of the perfect stage of the apple scab pathogen (Venturia inaequalis) under field conditions. J. Plant Dis. 97:24-32.

43. Mills, W. D. 1944. Efficient use of sulfur dusts and sprays during rain to control apple scab. Cornell Ext. Bull. 630:1-4.

44. Olaya, G., Zheng, D., and Köller, W. 1998. Differential responses of germinating Venturia inaequalis conidia to kresoxim-methy. Pestic. Sci. 54:230-236.

45. Palmiter, D. H. 1946. Ground treatments as an aid in apple scab control. N. Y. Agric. Exp. Stn. Bull. No. 714.

46. Philion, V., Carisse, O., and Paulitz, T. 1997. In vitro evaluation of fungal isolates for their ability to influence leaf rheology, production of pseudothecia, and ascospores of Venturia inaequalis. Eur. J. Plant Pathol. 103:441-452.

47. Rosenberger, D. A. 1990. Apple disease management. Pages 40-45 in: Management guide for low-input sustainable apple production. U.S. Dep. Agric. Sustain. Agric. Apple Prod. Proj. 33-49.

48. Ross, R. G., and Burchill, R. T. 1968. Experiments using sterilized appleleaf disks to study the mode of action of urea in suppressing perithecia of Venturia inaequalis (Cke) Wint. Ann Appl. Biol. 62:289-296.

49. Schneider, E. F., and Dickert, K. J. 1994. Health costs and benefits of fungicides used in agriculture: A literature review. J. Agromed. 1:19-37.

50. Scribner, F. L. 1888. Apple scab. Pages 331-347 in: U.S. Dep. Agric. Ann. Rep. 1887. Washington, D.C.

51. Sholberg, P. L., Yorston, J. M., and Warnock, D. 1989. Resistance of Venturia inaequalis to benomyl and dodine in British Columbia, Canada. Plant Dis. 73:667-669.

52. Smith, F. D., Parjer, D. M., and Koller, W. 1991. Sensitivity distribution of Venturia inaequalis to sterol demethylation inhibitor flusilazol: Baseline sensitivity and implications for resistance monitoring. Phytopathology 81:392-396

53. St-Arnaud, M., and Neumann, P. 1990. Un modèle d'estimation de l'état d'avancement de la période d'infection primaire par le Venturia inaequalis en verger de pommiers. Phytoprotection 71:73-84.

54. Sutton, D. K., MacHardy, W. E., and Lord, W. G. 2000. Effect of shredding or treating apple leaves litter with urea on ascospore dose of Venturia inaequalis and disease buildup. Plant Dis. 84:1319-1326.

55. Vincent, C., Rancourt, B., and Carisse, O. Apple leaf shredding as a nonchemical tool to manage apple scab and spotted tentiform leafminer. Agric. Ecosyst. Environ. (In Press.)

56. Young, C. S., and Andrews, J. H. 1990. Inhibition of pseudothecial development of Venturia inaequalis by the basidiomycete Athelia bombacina in apple leaf litter. Phytopathology 80:536-542. 